\title{
КОМБІНОВАНИЙ РЕГУЛЬОВАНИЙ ПОЛЯРИЗАТОР
}

\section{А.В. Булашенко ${ }^{1}$, С.І. Пільтяй ${ }^{1}$, С.І. Калініченко ${ }^{1}$,}

О.В. Булашенко ${ }^{2}$, І.В. Забегалов

${ }^{1}$ Київський політехнічний інститут ім. Ігоря Сікорського

${ }^{2}$ Шосткинський фаховий коледж ім. Івана Кожедуба

a.bulashenko@kpi.ua, s.piltiai@kpi.ua,kaliza@ukr.net

Останнім часом поляризаційні пристрої набувають широкого поширення у сучасних телекомунікаційних системах. Найбільш поширенішими 3 конструкторської точки зору являються поляризатори, що будуються на основі реактивних неоднорідностей всередині прямокутних хвилеводів у вигляді штирів [1-2] та діафрагм [3-4]. Такі пристрої $є$ у радіолокаційних, супутникових, та радіонавігаційних системах. Існує багато таких пристроїв, що моделюються у різних програмах, наприклад HFSS та CST MS [5-7]. Але робіт, що присвячені розробці моделей цих пристроїв мало [8-9], тому є актуальною задача створення нових аналітичних моделей.

Будемо розглядати хвилевідний поляризаційний пристрій, що поєднує в собі реактивності двох типів: штир та діафрагми (рис. 1 а). Циліндричний металевий штир необхідні, щоб здійснювати операцію підстройки характеристик. Модель пристрою хвилевід всередині якого розміщений штир та дві діафрагми.

На рис. 16 представлена еквівалента схема, що грунтується на основі методу еквівалентних схем [10].

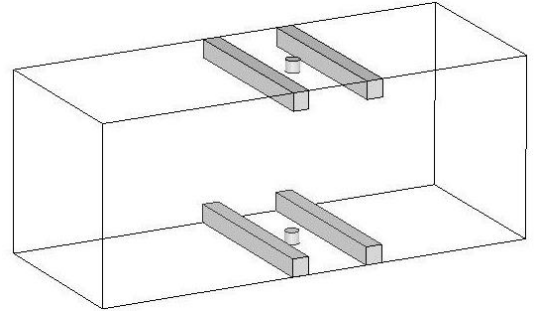

a)

Рис. 1

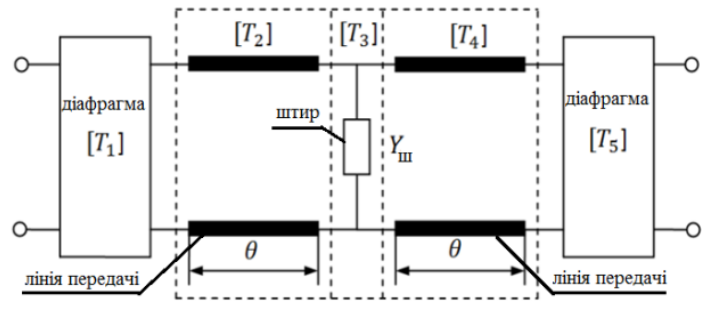

б)

Далі використовуючи метод хвильових матриць [11] отримуємо основні параметри загальної хвильової матриці розсіювання

$$
\left[S_{\Sigma}\right]=\left[\begin{array}{ll}
S_{11 . \Sigma} & S_{12 . \Sigma} \\
S_{21 . \Sigma} & S_{22 . \Sigma}
\end{array}\right] .
$$

Через ці параметри визначаємо основні характеристики пристрою. До цих характеристик належить диференційний фазовий зсув (рис. 2 a) та коефіцієнт відбиття (рис. 2 б) у робочому діапазоні частот. Із рис. 2 а видно, що фазовий зсув пристрою набуває значень $90 \pm 6.2^{\circ}$. Такий зсув $є$ припустимим серед існуючих аналогів [12-15]. 
Відмітимо, що на границях смуги пропускання спостерігається найбільше відхилення фази від $90^{\circ}$.

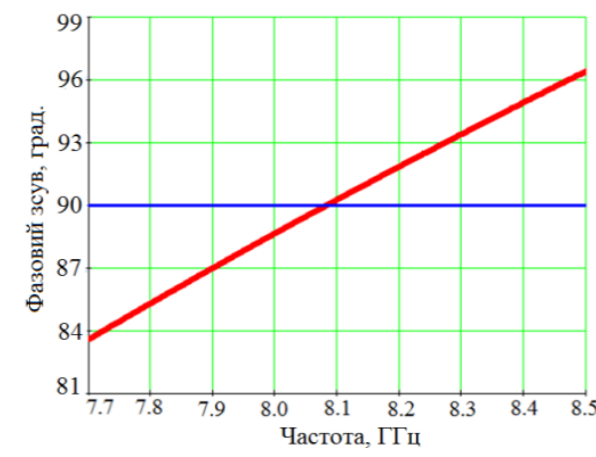

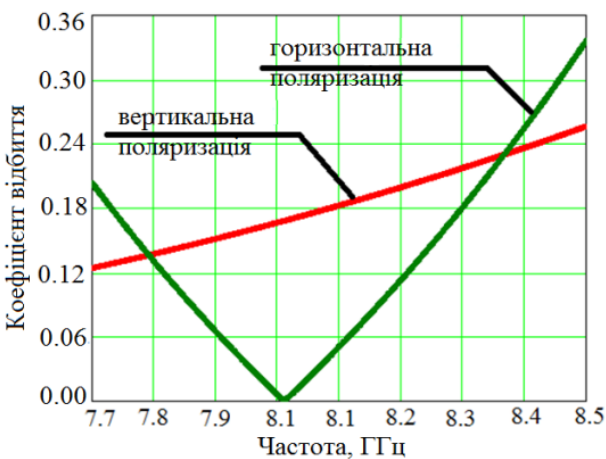

6

Рис. 2

Рис. 2 б ілюструє залежність коефіцієнта відбиття від частоти. Підкреслимо, що для обох поляризації максимальне значення коефіцієнту відбиття становить 0.36. Це свідчить про досить непогане узгодження пристрою.

Отже, було створено модель комбінованого хвилевідного поляризатора із діафрагмами та штирем. Він забезпечує фазовий зсув $90 \pm 6.2^{\circ}$ із коефіцієнтом відбиття 0,36 у робочому діапазоні частот.

Список літературних джерел

1. Piltyay S., Bulashenko A., Kushnir H., Bulashenko O. (2020) Information resources economy in satellite systems based on new microwave polarizers with tunable posts, Path of Science, Vol. 6, No 11, pp. 5001-5010. http://doi.org/10.22178/pos.55-1.

2. Bulashenko A., Piltyay S., Kalinichenko Ye., Bulashenko O. (2020) Mathematical modeling of iris-post sections for waveguide filters, phase shifters and polarizers, IEEE 2nd International Conference on Advanced Trends in Information Theory, pp. 330-336, Kyiv, Ukraine. http://doi.org/10.1109/ATIT50783.2020.9349321.

3. Bulashenko A.V., Piltyay S.I., Demchenko I.V. (2020) Optimization of a polarizer based on a square waveguide with irises. Science-Based Technologies, Vol 47, No 3, pp. 287-297. (in Ukrainian). http://doi.org/10.18372/2310-5461.47.14878.

4. Piltyay S.I., Bulashenko A.V., Kalinichenko Ye.I., Bulashenko O.V. (2020) High performance waveguide polarizer for satellite information systems, Visnyk Cherkaskogo derzhavnogo tehnologichnogo universitetu, Vol. 4, pp. 14-26. (in Russian). DOI: 10.24025/2306-4412.4.2020.217129.

5. Piltyay S.I., Sushko O.Yu., Bulashenko A.V. and Demchenko I. V. (2020) Compact Ku-band iris polarizers for satellite telecommunication systems. Telecommunications and Radio Engineering, Vol 79, No19, pp. 1673-1690. http://doi.org/10.1615/TelecomRadEng.v79.i19.10. 